\title{
Dipeptidyl peptidase-IV inhibitory peptides derived from salmon milt and their effects on postprandial blood glucose level
}

\author{
Yoshinori Takahashi ${ }^{1}\left[0\right.$ - Akira Kamata ${ }^{1} \cdot$ Tatsuya Konishi $^{1}$
}

Received: 25 March 2021 / Accepted: 9 June 2021 / Published online: 16 June 2021

(c) The Author(s) 2021

\begin{abstract}
The hydrolysate of Oncorhynchus keta (chum salmon) milt was found to exhibit strong inhibitory activity against dipeptidyl peptidase-IV (DPP-IV), and the hypoglycaemic effect of these salmon milt peptides (SMPs) was confirmed using oral starch tolerance tests in Sprague-Dawley rats. Specifically, the oral administration of SMPs at a dose of $300 \mathrm{mg} / \mathrm{kg}$ body weight for 1 week resulted in a significant decrease in the blood glucose level of the rats $60 \mathrm{~min}$ after starch consumption compared with the control. The bioassay-guided separation of SMPs, using a combination of column chromatographic techniques, led to the identification of 12 active di-, tri- and tetrapeptides, including four novel DPP-IV inhibitory peptides, namely PhePro-Val-Gly, Leu-Pro-Val-Leu, Val-Pro-Phe-Pro and Ile-Pro-Leu. Among these 12 peptides, Ile-Pro contributed the most $(1.3 \%)$ to the total DPP-IV inhibitory activity of SMPs. Therefore, SMPs may have the potential to be used as a suppressor of postprandial hyperglycaemia and to be considered a promising functional food material for the prevention of type II diabetes.
\end{abstract}

Keywords Salmon milt peptides $\cdot$ DPP-IV inhibitory peptides $\cdot$ Ile-Pro $\cdot$ Postprandial hypoglycaemic suppression · Sprague-Dawley rats $\cdot$ Oral starch tolerance test

\section{Introduction}

Diabetes, which is caused by a lack of insulin action, is a metabolic disease that is characterised by chronic hyperglycaemia. Specifically, blood glucose control can not only suppress the onset of diabetes, but also hinder the development of related complications, such as retinopathy, nephropathy, neuropathy, myocardial infarction and cerebral infarction. It can also improve the quality of life and life expectancy of patients. In Japan, more than $95 \%$ of patients with diabetes are considered to have type II diabetes (non-insulindependent diabetes). Recently, dipeptidyl peptidase IV (DPP-IV) inhibitors, such as sitagliptin and alogliptin, have

Yoshinori Takahashi

yo-takahashi@maruha-nichiro.co.jp

Akira Kamata

a-kamata@maruha-nichiro.co.jp

Tatsuya Konishi

t-konishi@maruha-nichiro.co.jp

1 Central Research Institute, Maruha Nichiro Corporation, 16-2, Wadai, Tsukuba, Ibaraki 300-4295, Japan been approved as new type II diabetes drugs (Andukuri et al. 2009; Gallwitz 2007). Such compounds have attracted particular attention owing to their ability to control blood glucose levels with fewer side effects than other commonly used diabetes drugs. More specifically, DPP-IV degrades incretin, which is a gastrointestinal hormone with actions similar to those of gastric inhibitory polypeptide (GIP) and glucagonlike peptide-1 (GLP-1) (Drucker 2003). These hormones act on pancreatic $\beta$-cells to promote the secretion of insulin in an inactive form. Therefore, DPP-IV inhibitors can maintain the activity of incretin and promote the secretion of insulin. Furthermore, DPP-IV is a serine protease that recognises and cleaves the second proline (Pro) or alanine (Ala) residue in the N-terminal of peptides, and it has been reported to act strongly on peptides possessing Pro and Ala at the second residue of the $\mathrm{N}$-terminal as well on those possessing lysine (Lys) and arginine (Arg) as the $\mathrm{N}$-terminal residue (Davy et al. 2000).

Although several compounds with the ability to inhibit DPP-IV have been obtained via chemical synthesis, these are associated with numerous safety issues and adverse side effects. Reports of DPP-IV inhibitors derived from natural products include peptides derived from whey 
protein hydrolysates (Lacroix et al. 2016; Nongonierma and FitzGerald 2013; Tulipano et al. 2011) and those derived from camel milk protein (Nongonierma et al. 2018), Porphyra dioica protein hydrolysates (Cermeño et al. 2019), peptides derived from Euphausia superba (Antarctic krill) protein (Ji et al. 2017a, b), and hydrolysates derived from gelatin extracted from salmon skin (Cheung and Li-Chan 2017; Jin et al. 2020; Li-Chan et al. 2012; Neves et al. 2017b) and muscle (Ketnawa et al. 2019; Neves et al. 2017a).

Our institution, a fishery company, is interested in developing new products by identifying novel functions of materials based on a range of fishery resources. In particular, the application of unused resources contributes to the effective utilisation of limited resources and to a reduction in environmental impact and has significance from a sustainable development goal perspective. In addition, to date the utilisation value of milt from seafood is lower than that of roe, with applications limited to fertiliser or feed. Additionally, salmon milt, which is relatively widely used in Japan, accounts for more than 10,000 tons of industrial waste annually. Thus, in this study, we investigated new salmon milt peptides (SMPs) that exhibit DPP-IV inhibitory activity and examined their ability to suppress postprandial hyperglycaemia. Additionally, we identified the peptides present in SMPs.

\section{Material and methods}

\section{Materials}

Milt of Oncorhynchus keta (chum salmon), a fishery processing by-product, was obtained from Peter Pan Seafoods Inc. (Valdez, AK, USA). All enzymes were purchased from Amano Enzyme Inc. (Aichi, Japan), and the reagents required for peptide synthesis were purchased from Tokyo Chemical Industry Co., Ltd. (Tokyo, Japan). The DPPIV inhibitory activity of the isolated SMPs was measured using a commercial in vitro enzymatic assay based on the DPP-IV Drug Discovery Kit (Enzo Life Sciences Inc., Enzo
Biochem, Farmingdale, NY, USA), and acetonitrile (LC-MS grade), methanol (LC-MS grade), chloroform and formic acid were purchased from Kanto Chemicals (Tokyo, Japan).

\section{Preparation of test substances}

\section{Enzyme selection}

Minced chum salmon milt ( $8 \mathrm{~g}$ ) was added to distilled water $(15 \mathrm{~mL})$ and the $\mathrm{pH}$ of the resulting solution was adjusted to ensure optimal $\mathrm{pH}$ conditions for the functioning of each enzyme using a $2 \mathrm{M} \mathrm{NaOH}$ or $1 \mathrm{M} \mathrm{HCl}$ solution. The enzymes and reaction conditions are listed in Table 1. After preincubation at the optimal temperature for $15 \mathrm{~min}, 2.0 \mathrm{mg}$ ( $1 \%$ by dry weight) of each enzyme was added and the mixture was stirred for $4 \mathrm{~h}$. Thereafter, the reaction solution was heated to $90{ }^{\circ} \mathrm{C}$ to inactivate the enzyme, and the solution was filtered through Celite. The filtrate was then lyophilised to obtain the hydrolysate, whose DPP-IV inhibitory activity was then evaluated.

\section{Preparation of SMPs}

Minced salmon milt ( $7.2 \mathrm{~kg}$ ) was hydrolysed using protease (17.5 g; from Aspergillus melleus; Amano Enzyme Inc.) for $>5 \mathrm{~h}$ at $50{ }^{\circ} \mathrm{C}$. Thereafter, the reaction mixture was heated to $90{ }^{\circ} \mathrm{C}$ and maintained at this temperature for $15 \mathrm{~min}$ to inactivate the enzyme. The reaction mixture was then filtered through Celite. The higher molecular weight components were then removed via ultrafiltration (Pellicon ${ }^{\circledR} 5 \mathrm{~K}$ PLCCC; MilliporeSigma, Burlington, MA, USA), whereas the lower molecular weight components were evaporated and dried to obtained SMPs.

\section{DPP-IV inhibitory activity}

The DPP-IV inhibitory activity of SMPs was measured using a commercial in vitro enzymatic assay that involved the use of the DPP-IV Drug Discovery Kit (Enzo Life Sciences Inc.), with a slight modification of the manufacturer's

Table 1 Enzyme screening

\begin{tabular}{llllll}
\hline Enzyme & Origin & $\mathrm{pH}$ & $\begin{array}{l}\text { Tempera- } \\
\text { ture }\left({ }^{\circ} \mathrm{C}\right)\end{array}$ & Yield (\%) & $\begin{array}{l}\text { DPP-IV inhibi- } \\
\text { tory activity } \\
(\%)^{\mathrm{a}}\end{array}$ \\
\hline Protease P "Amano" 3SD & Aspergillus melleus & 8.0 & 50 & 4.6 & 59.2 \\
Bioprase OP & Bacillus clausii & 9.5 & 60 & 4.8 & 41.1 \\
Protease M "Amano" SD & Aspergillus oryzae & 6.0 & 50 & 2.4 & 50.3 \\
Orientase 20A & Aspergillus niger & 3.3 & 50 & 3.5 & 55.3 \\
Aroase AP-10 & Bacillus subtilis & 7.0 & 50 & 3.2 & 43.5 \\
Umamizyme G & Aspergillus oryzae & 8.0 & 50 & 4.9 & 53.8 \\
\hline
\end{tabular}

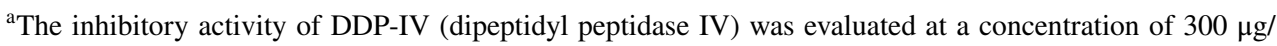
$\mathrm{mL}$ 
instructions. Specifically, the assay was performed in 96-well plates using Ile-Pro-Ile (Diprotin A) as a positive control. Different concentrations of the test samples $(10 \mu \mathrm{L})$ were pre-incubated with $50 \mathrm{mM}$ Tris buffer $(25 \mu \mathrm{L}, \mathrm{pH} 7.5)$ and $0.01 \mathrm{mM}$ AMC (50 $\mu \mathrm{L}$; H-Gly-Pro-amino-4-methylcoumarine, BML-P189-9090; Biomol GmbH, Hamburg, Germany) at $37^{\circ} \mathrm{C}$ for $10 \mathrm{~min}$. The assay was started after the addition of recombinant human DPP-IV ( $15 \mu \mathrm{L}, 2 \mathrm{mU} / \mathrm{mL})$. Plates were read at fluorescence wavelengths of $340 \mathrm{~nm}$ (excitation) and $460 \mathrm{~nm}$ (emission) using a microplate reader (GENio Pro; Tecan Co., Tecan Group Ltd., Männedorf, Switzerland) at 5-min intervals between 0 and $30 \mathrm{~min}$. The recorded data were plotted against time, and the best-fit straight line was obtained in the time range over which the increase in relative fluorescence units was linear. The data were expressed as the percentage of remaining activity in the presence of the test sample versus the control (without sample). For each sample, three different assays were performed, and those curves showing the logarithmic regression of the dose-response curves were plotted to determine the $50 \%$ inhibitory concentration $\left(\mathrm{IC}_{50}\right)$ values of the DPP-IV activity. In addition, the contribution ratio of each identified peptide to the DPP-IV inhibitory activity of SMPs was obtained using the following formula (Seki et al. 1996):

Contribution ratio $(\%)=(A p / I p) /(1,000,000 / I s) \times 100$

where $A p$ represents the proportion of the DPP-IV inhibitory peptide to SMPs (ppm), Ip represents the $\mathrm{IC}_{50}$ value of the inhibitory peptide $(\mu \mathrm{g} / \mathrm{mL})$ and $I s$ represents the $\mathrm{IC}_{50}$ value of SMPs $(\mu \mathrm{g} / \mathrm{mL})$.

\section{Evaluation of the postprandial hypoglycaemic effect of SMPs in Sprague-Dawley rats}

Male Sprague-Dawley (SD) rats (SLC Inc., Shizuoka, Japan), aged 6 weeks, were used in this study. The rats, which were housed in a ventilated room maintained at $25 \pm 3{ }^{\circ} \mathrm{C}$ with $50 \pm 9 \%$ relative humidity, under an alternating $12 \mathrm{~h} / 12 \mathrm{~h}$ light/dark cycle, were fed a solid diet (CRF-1; Oriental Yeast Co., Ltd., Tokyo, Japan) for 1 week. Thereafter, they were divided into three groups of ten rats, namely, the 0,150 , and $300 \mathrm{mg} / \mathrm{kg}$ SMPs-treated groups, respectively. After treatment for 1 week, the rats were fasted for $16 \mathrm{~h}$, and $2 \mathrm{~g}$ starch per kilogram body weight $(2 \mathrm{~g} / \mathrm{kg})$ was orally administered concurrently with 0,150 , or $300 \mathrm{mg} / \mathrm{kg}$ of SMPs. Blood samples were then taken from the tail at 0 , 30,60 and 120 min after treatment administration, and the blood glucose levels were measured using a blood glucose monitoring system (Freestyle Freedom ${ }^{\mathrm{TM}}$; NIPRO Corp., Osaka, Japan). The blood glucose levels were compared with those of the rats in the control group, which had not been exposed to SMPs. All experiments were carried out in accordance with the protocols and guidelines approved by the animal care committee of KAC Co., Ltd. Kyoto, Japan).

\section{Bioassay-guided separation and analysis of SMPs}

The SMPs separation process utilised in the present study is outlined in Fig. 1. Specifically, SMPs (50 g) were subjected to column chromatography using a DIAION HP20 column (650 g; Mitsubishi Chemicals, Mitsubishi Chemical Holdings Corp., Tokyo, Japan). After being charged in the column, the sample was eluted using a stepwise elution system as follows: $5 \mathrm{~L}$ of distilled water (fraction 1-1), $3 \mathrm{~L}$ of $50 \%$ (v/v) hydrous methanol (fraction 1-2) and $5 \mathrm{~L}$ of methanol (fraction 1-3). Each fraction was evaluated for its DPP-IV inhibitory activity, and fraction 1-2 (5.0 g), which showed the strongest inhibitory activity, was further separated using a silica gel chromatographic column (Hi Flash Column, $250 \mathrm{~g}, \varphi 60 \times 180 \mathrm{~mm}$; Yamazen Corp., Osaka, Japan) with a stepwise solvent system consisting of chloroform/metha$\mathrm{nol} /$ water $(\mathrm{C} / \mathrm{M} / \mathrm{W})$. This fraction was further separated into eight fractions as follows: $2.5 \mathrm{~L}$ of $\mathrm{C} / \mathrm{M} / \mathrm{W}$ at 85/15/1 (fraction 2-1), $1 \mathrm{~L}$ of $\mathrm{C} / \mathrm{M} / \mathrm{W}$ at $65 / 16 / 2$ (fraction $2-2$ ), $1.5 \mathrm{~L}$ of $\mathrm{C} / \mathrm{M} / \mathrm{W}$ at $65 / 16 / 2$ (fraction 2-3), $0.4 \mathrm{~L}$ of $\mathrm{C} / \mathrm{M} / \mathrm{W}$ at $65 / 25 / 4$ (fraction 2-4), 2.1 L of $\mathrm{C} / \mathrm{M} / \mathrm{W}$ at $65 / 25 / 4$ (fraction 2-5), 2.5 $\mathrm{L}$ of $\mathrm{C} / \mathrm{M} / \mathrm{W}$ at $6 / 4 / 1$ (fraction 2-6), $2.5 \mathrm{~L}$ of $\mathrm{C} / \mathrm{M} / \mathrm{W}$ at $4 / 6 / 1$ (fraction 2-7) and 2.5 $\mathrm{L}$ of methanol/2.5 $\mathrm{M} \mathrm{NH}_{3}$ aqueous solution at $1 / 1$ (fraction 2-8).

Given that fractions 2-3 and 2-4 exhibited the strongest DPP-IV inhibitory activities, fraction 2-3 (45 mg) was further fractionated using hydrous methanol in an ODS silica gel chromatographic column (Hi Flash Column, 14 g, $\varphi 20 \times$

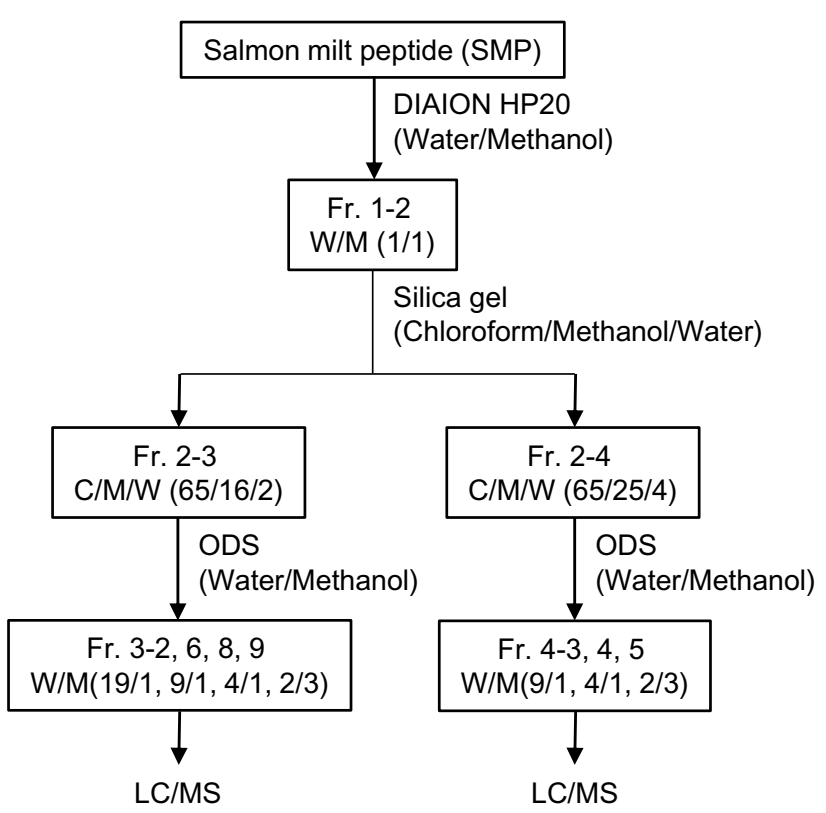

Fig. 1 Flow diagram of separation process of salmon milt peptides 
$65 \mathrm{~mm}$; Yamazen Corp.). The column was eluted and fractionated using a stepwise solvent system, and ten fractions were obtained: $300 \mathrm{~mL}$ of water (fraction 3-1), $150 \mathrm{~mL}$ of $5 \%$ methanol (fraction 3-2), $150 \mathrm{~mL}$ of $5 \%$ methanol (fraction 3-3), $150 \mathrm{~mL}$ of $5 \%$ methanol (fraction 3-4), $150 \mathrm{~mL}$ of $10 \%$ methanol (fraction $3-5$ ), $150 \mathrm{~mL}$ of $10 \%$ methanol (fraction 3-6), $150 \mathrm{~mL}$ of $10 \%$ methanol (fraction 3-7), $150 \mathrm{~mL}$ of $20 \%$ methanol (fraction $3-8$ ), $150 \mathrm{~mL}$ of $40 \%$ methanol (fraction 3-9) and $150 \mathrm{~mL}$ of methanol (fraction 3-10). Additionally, fraction 2-4 (247 mg) was fractionated using hydrous methanol in an ODS chromatographic column (Hi Flash Column, 14 g, $\Phi 20 \times 65$ mm; Yamazen Corp.). After elution, this fraction was again divided into the following fractions: $300 \mathrm{~mL}$ of water (fraction 4-1), $150 \mathrm{~mL}$ of $5 \%$ methanol (fraction 4-2), $150 \mathrm{~mL}$ of $10 \%$ methanol (fraction 4-3), $150 \mathrm{~mL}$ of $20 \%$ methanol (fraction $4-4$ ), $150 \mathrm{~mL}$ of $40 \%$ methanol (fraction $4-5$ ), $150 \mathrm{~mL}$ of $60 \%$ methanol (fraction 4-6) and $150 \mathrm{~mL}$ of methanol (fraction 4-7).

\section{Peptide synthesis}

The synthetic peptides were prepared using the conventional Fmoc-solid-phase synthesis method with a peptide synthesiser (SyroI; Biotage Uppsala, Sweden). Fmoc-amino acid resin (HMP preloaded, $40 \mathrm{mmol}$ ) was used to synthesise the C-terminal, and Fmoc-amino acid ( $1 \mathrm{mmol}$ ) was used to realise the extension of the peptide chain. The synthesised peptide resin was cleaved using a mixture of TFA/triethylsilane/water $(2 \mathrm{~mL}, 95 / 3 / 2)$ for a duration of $>2 \mathrm{~h}$, after which it was filtered and the filtrate subsequently evaporated. The obtained residue was eluted from the resin using $10 \%(\mathrm{v} / \mathrm{v})$ acetic acid $(2 \mathrm{~mL})$, following which dichloromethane $(2 \mathrm{~mL})$ was added. After stirring, the organic layer was removed by pipetting, and the same procedure was repeated three times. Following the subsequent evaporation of the aqueous layer, the residue was purified using an ODS silica gel chromatographic column (Sep Pak Vac 6 cc [1 g] $\mathrm{C}_{18}$ cartridge; Waters Corp., Milford, MA, USA) with different concentrations of methanol and $0.1 \%(\mathrm{v} / \mathrm{v})$ aqueous trifluoroacetic acid (TFA).

\section{Spectral analysis}

The various fractions and the synthesised peptides were analysed using LCMS-IT-TOF (combined liquid chromatography [LC] system and high-performance ion trap/time-of-flight [ITTOF] mass spectrometry [MS]). Chromatographic separations were performed on an XTerra MS $\mathrm{C}_{18}$ column $(2.1 \times 100 \mathrm{~mm}$, $3.5 \mu \mathrm{m}$ particle size; Waters Corp.). Further, a gradient programme was employed with a mobile phase combining solvent A (0.1\% TFA in water) and solvent B (methanol) as follows: $3 \% \mathrm{~B}(0-15 \mathrm{~min}$ ), 3-60\% (15-45 $\mathrm{min})$ and 60\% (45-50 min). The flow rate was $0.1 \mathrm{~mL} / \mathrm{min}$, and the column and sample temperature were maintained at 40 and $15{ }^{\circ} \mathrm{C}$, respectively. Mass spectrometric detection was performed on an LCMSIT-TOF spectrometer (Shimadzu Corp., Kyoto, Japan) with an electrospray ionisation (ESI) source.

\section{Quantitative analysis of SMPs}

The quantitative determination of the concentrations of the inhibitory peptides in the SMPs was carried out by LC-MS/ MS. Specifically, chromatographic separation was performed on an ACQUITY HSS PFP column $(2.1 \times 150 \mathrm{~mm}, 1.8 \mu \mathrm{m}$ particle size; Waters Corp.). A gradient programme with a mobile phase combining solvent $\mathrm{A}(0.1 \%$ formic acid in water $)$ and solvent B (methanol) was employed as follows: 20-72\% $\mathrm{B}(0-15 \mathrm{~min})$. The flow rate was $0.2 \mathrm{~mL} / \mathrm{min}$ and the injection volume was $2 \mu \mathrm{L}$; the column and sample temperatures were maintained at 40 and $15^{\circ} \mathrm{C}$, respectively.

Mass spectrometric detection was realised using a Xevo TQD triple quadruple mass spectrometer equipped with an ESI source in the positive mode (Waters Corp.). The quantitative analysis of the inhibitory peptides was performed using the multiple reaction monitoring (MRM) method. The dwell time was set to $25 \mathrm{~ms}$ for each MRM transition, and the MRM transition channels (Q1/Q3) and the cone/collision energies (CE) of the inhibitory peptides were set as follows: Ile-Pro, 229.1/86.0 (8/16 V); Leu-Pro, 229.1/116.0 (4/12 V); Phe-Pro, 263.1/116.0 (28/14 V); Val-Pro-Ile, 328.2/229.1 (4/28 V); Val-Pro-Leu, 328.2/229.1 (32/16 V); Ile-Pro-Ile, 342.1/229.1 (4/18 V); Leu-Pro-Leu, 342.1/229.1 (32/16 V); Ile-Pro-Leu, 342.2/229.1 (34/18 V); Leu-Pro-Phe, 376.1/263.2 (36/18 V); Phe-Pro-Val-Gly, 419.2/120.0 (40/38 V); Leu-Pro-Val-Leu, 441.3/169.1 (42/32 V); and Val-Pro-Phe-Pro, 459.2/197.1 (42/24 V). Further, the optimal MS parameters were: capillary voltage, $3.15 \mathrm{kV}$; desolvation temperature, $50{ }^{\circ} \mathrm{C}$. Data acquisition and processing were performed using Analyst software (MassLynx; Waters Corp.).

\section{Statistical analysis}

All assays were performed at least in triplicate. Each data point is presented as the mean of results corresponding to three samples that had been subjected to analysis of variance followed by Dunnett's test. $p<0.05$ were considered to indicate statistically significant differences, and all analyses were performed using SPSS software (ver. 27; IBM Corp., Armonk, NY, USA). 


\section{Results}

\section{Enzyme selection}

Food-grade enzymes were selected based on their DPP-IV inhibitory activity and yield (Table 1). Among these, Protease $\mathrm{P}$ "Amano" 3SD, which was derived from Aspergillus melleus, exhibited the strongest DPP-IV inhibitory activity (59.2\% at a concentration of $300 \mu \mathrm{g} / \mathrm{mL}$ ), and its yield from wet salmon milt was $4.6 \% \mathrm{w} / \mathrm{w}$.

\section{Postprandial hypoglycaemic effect of SMPs}

To clarify the postprandial hypoglycaemic effect of SMPs, the oral starch tolerance test was performed in SD rats. Specifically, SMPs were administered to the SD rats at doses of 0,150 , and $300 \mathrm{mg} / \mathrm{kg}$ body weight. The blood glucose concentrations as well as the area under the curve (AUC) at the different measurement times are shown in Table 2. In the $300 \mathrm{mg} / \mathrm{kg}$ SMPs group, the blood glucose level at 30 and 60 min after SMPs administration was lower and significantly lower than that in the control group, respectively. Additionally, the AUC of the $300 \mathrm{mg} / \mathrm{kg}$ SMPs group was significantly lower than that of the control group.

\section{Separation and identification of DPP-IV inhibitory peptides in SMPs}

The DPP-IV inhibitory activity of SMPs at a concentration of $300 \mu \mathrm{g} / \mathrm{mL}$ was found to be $37.1 \%$. After the initial column separation on the Diaion HP20 column, fraction 1-2, which was eluted with $50 \%$ hydrous methanol, with a yield of $7.3 \mathrm{~g}$, showed the strongest inhibitory activity (63.2\%). Further fractionation of this fraction by silica gel column chromatography using a stepwise solvent system consisting of $\mathrm{C} / \mathrm{M} / \mathrm{W}$ resulted in eight fractions. Fractions 2-3 (yield $60.5 \mathrm{mg}$ ) and 2-4 (yield $290.6 \mathrm{mg}$ ) were found to exhibit a strong DPP-IV inhibitory activity (at a concentration of $200 \mu \mathrm{g} / \mathrm{mL}, 68.7 \%$ for fraction $2-3$ and $91.0 \%$ for fraction $2-4)$, and each of these fractions was further separated by
ODS column chromatography. All of the isolated fractions were evaluated for their DPP-IV inhibitory activities, and LC-MS analysis was performed on the more active fractions. The amino acid composition of the peptide in each fraction was estimated based on the mass number detected through LC-MS analysis. Subsequently, the predicted peptide was synthesised and analysed using LC-TOF-MS, and the peptides in SMPs were identified by comparing the retention time and the specific mass number. In this way, a total of 12 active DPP-IV inhibitory peptides were identified from SMPs, as shown in Table 3.

The contribution ratios of the identified peptides were calculated from their respective $\mathrm{IC}_{50}$ values and contents as previously described (Seki et al. 1996). Further, the identified peptides were quantified via MS using a Xevo TQD triple quadrupole mass spectrometer equipped with a positive-mode ESI source. The contribution ratio of each dipeptide against SMPs with respect to the inhibition of DPP-IV activity is shown in Table 4. Among the identified peptides, Val-Pro-Ile and Ile-Pro-Ile showed the strongest DPP-IV inhibitory activities, with $\mathrm{IC}_{50}$ values of $1.0 \mu \mathrm{g} / \mathrm{mL}$. The newly identified compounds, namely Ile-Pro-Leu, Phe-ProVal-Gly, Leu-Pro-Val-Leu and Val-Pro-Phe-Pro, also showed low $\mathrm{IC}_{50}$ values $(9.0,17.2,20.4$, and $10.0 \mu \mathrm{g} / \mathrm{mL}$, respectively). Thus, the major peptides in the SMPs sample were found to be dipeptides, namely Leu-Pro, Ile-Pro and Phe-Pro (527, 360 and $246 \mathrm{ppm}$, respectively). These peptides had low $\mathrm{IC}_{50}$ values whereas their high content resulted in a high contribution.

\section{Discussion}

The prevalence of metabolic syndromes, including glucose intolerance, is a serious health problem that requires the development of effective preventive and therapeutic methods. Additionally, in the context of diabetes, impaired glucose tolerance is associated with an impaired action of insulin (insulin resistance) or the prevention of insulin secretion from pancreatic $\beta$-cells. GLP-1 is a gastrointestinal hormone produced by gastrointestinal secretory cells ( $\mathrm{L}$ cells) that
Table 2 Blood glucose levels in the oral starch tolerance test

\begin{tabular}{llllll}
\hline Experimental groups & \multicolumn{2}{l}{ Blood glucose level $(\mathrm{mg} / \mathrm{dL})$} & AUC \\
\cline { 2 - 5 } & Before administration & After 30 min & After 60 min & After 120 min & \\
\hline Control & $63.4 \pm 6.3$ & $137.6 \pm 18.8$ & $123.7 \pm 8.5$ & $76.7 \pm 9.3$ & $215.8 \pm 15.8$ \\
$150 \mathrm{mg} / \mathrm{kg}$ & $64.9 \pm 7.8$ & $126.2 \pm 16.5$ & $122.4 \pm 8.9$ & $73.1 \pm 8.6$ & $207.7 \pm 13.0$ \\
$300 \mathrm{mg} / \mathrm{kg}$ & $63.5 \pm 9.2$ & $123.1 \pm 14.0$ & $114.5 \pm 9.9^{\#}$ & $73.1 \pm 7.7$ & $200.3 \pm 13.3^{\#}$ \\
\hline
\end{tabular}

Values are presented as the mean of triplicate measurements \pm standard deviation (SD); $n=10$

$A U C$ Area under the curve

${ }^{\#}$ Significant difference at $p<0.05$ between the control group and each salmon milt peptides (SMPs)-treated group (Dunnett's $t$ test) 
Table 3 DPP-IV inhibitory activities of identified peptides from salmon milt peptides

\begin{tabular}{|c|c|c|c|c|c|}
\hline Fraction & $\begin{array}{l}\text { DPP-IV inhibi- } \\
\text { tory activity }\end{array}$ & {$[\mathrm{M}+\mathrm{H}]^{+}(\mathrm{m} / \mathrm{z})$} & Fragment ion $(\mathrm{m} / \mathrm{z})$ & $\begin{array}{l}\text { Retention } \\
\text { time (min) }\end{array}$ & Identified peptide \\
\hline \multirow[t]{2}{*}{$3-2$} & 78.7 & 229.1542 & 116.0714 & 32.35 & Ile-Pro \\
\hline & & 229.1570 & 116.0718 & 33.68 & Leu-Pro \\
\hline \multirow[t]{2}{*}{$3-6$} & 56.4 & 328.2218 & $229.1532,197.1277,169.1342$ & 38.57 & Val-Pro-Ile \\
\hline & & 328.2228 & $229.1532,197.1259,169.1343$ & 38.91 & Val-Pro-Leu \\
\hline \multirow[t]{3}{*}{$3-8$} & 65.6 & 342.2389 & $229.154,211.1439,183.1500$ & 35.64 & Ile-Pro-Ile \\
\hline & & 342.2400 & $229.1545,211.1441,183.1503$ & 42.96 & Ile-Pro-Leu \\
\hline & & 342.2394 & $229.1545,211.1444,183.1501$ & 43.32 & Leu-Pro-Leu \\
\hline \multirow[t]{2}{*}{$3-9$} & 53.3 & 376.2245 & $263.139,211.1445,183.1502,166.0875$ & 45.28 & Leu-Pro-Phe \\
\hline & & 441.3076 & $328.2217,310.2132,231.1693,211.1442,197.1282$ & 47.53 & Leu-Pro-Val-Leu \\
\hline $4-3$ & 51.6 & 263.1385 & $116.0718,120.0812$ & 38.17 & Phe-Pro \\
\hline $4-4$ & 38.5 & 419.2300 & $344.1958,272.1597,245.129,217.1339$ & 40.32 & Phe-Pro-Val-Gly \\
\hline $4-5$ & 35.7 & 459.2807 & $360.1919,344.198,263.1388,245.1293,197.1284$ & 44.30 & Val-Pro-Phe-Pro \\
\hline
\end{tabular}

The DPP-IV inhibitory activity was evaluated at a concentration of $50 \mu \mathrm{g} / \mathrm{mL}$

Table 4 DPP-IV inhibitory activity contribution ratios of the peptides against salmon milt peptides

\begin{tabular}{llll}
\hline Peptide & $\mathrm{IC}_{50}(\mu \mathrm{g} / \mathrm{mL})$ & Content $(\mathrm{ppm})$ & $\begin{array}{l}\text { Contribu- } \\
\text { tion ratio } \\
(\%)\end{array}$ \\
\hline Ile-Pro & 15.2 & 360 & 1.26 \\
Leu-Pro & 115.9 & 527 & 0.24 \\
Val-Pro-Ile & 1.0 & 2.49 & 0.13 \\
Val-Pro-Leu & 6.1 & 19.2 & 0.17 \\
Ile-Pro-Ile & 1.0 & 1.95 & 0.10 \\
Ile-Pro-Leu & 9.0 & 9.00 & 0.05 \\
Leu-Pro-Leu & 28.0 & 7.46 & 0.01 \\
Leu-Pro-Phe & 33.0 & 9.22 & 0.01 \\
Leu-Pro-Val-Leu & 20.4 & 12.4 & 0.03 \\
Phe-Pro & 112.7 & 246 & 0.12 \\
Phe-Pro-Val-Gly & 17.2 & 58.4 & 0.18 \\
Val-Pro-Phe-Pro & 10.0 & 160 & 0.85 \\
SMPs & 529 & $1.00 \times 10^{6}$ & 100 \\
\hline
\end{tabular}

$I C_{50} 50 \%$ inhibitory concentration

are abundant in the ileum and large intestine. This hormone exerts various effects, such as promoting insulin secretion from pancreatic $\beta$-cells and the proliferation of pancreatic $\beta$-cells and inhibiting apoptosis, and has been reported to also exhibits anorexigenic effects and to be rapidly cleaved at the N-terminal residues by DPP-IV in the blood, resulting in its inactive form. Thus, its half-life can be as short as approximately 2 min (Hansen et al. 1999). Additionally, given that the inhibition of blood DPP-IV prolongs the half-life of GLP-1, thereby allowing the effect of insulin to persist and enabling the decrease in blood glucose levels, DPP-IV inhibitors, such as sitagliptin and alogliptin, have been investigated and used as antidiabetics. Recently, several peptides derived from food materials have also been reported to exhibit DPP-IV inhibitory activity (Cermeño et al. 2019; Ji et al. 2017a; Jin et al. 2020; Ketnawa et al. 2019; Nongonierma et al. 2018). Therefore, we investigated the development of a functional food material with DPPIV inhibitory activity using chum salmon milt, which is an unused resource that is discarded in large quantities during fishery processing.

Initially, to hydrolyse the salmon milt, food-grade enzymes were selected based on their DPP-IV inhibitory activities and yields. Among these, Protease P "Amano" 3SD showed the strongest DPP-IV inhibitory activity (Table 1). Additionally, given that this enzyme also exhibited a good yield, it was used to prepare SMPs, which exhibited DPP-IV inhibitory activity with an $\mathrm{IC}_{50}$ value of $529 \mu \mathrm{g} / \mathrm{mL}$, which is stronger than that of whey protein hydrolysate $(1.33 \mathrm{mg} /$ $\mathrm{mL}$ ) (Nongonierma and FitzGerald 2013), peptides derived from Antarctic krill protein (1.6272 mg/mL; Ji et al. 2017a) and hydrolysates derived from gelatin extracted from salmon skin $(1.54 \mathrm{mg} / \mathrm{mL}$; Jin et al. 2020) and muscle $(4.8 \mathrm{mg} / \mathrm{mL}$; Ketnawa et al. 2019), which are food materials with DPP-IV inhibitory activity. Subsequently, an oral starch tolerance test involving SD rats was realised, and the active ingredients were identified. As shown in Table 2, in the $300 \mathrm{mg} / \mathrm{kg}$ SMPs group, the blood glucose level at $60 \mathrm{~min}$ after SMPs administration as well as the AUC were significantly lower than those corresponding to the control group. These findings show that SMPs exhibit a suppressive effect on postprandial hyperglycaemia.

We then investigated the SMPs components that were active against DPP-IV. Using the level of DPP-IV inhibitory activity as an index, the bioassay-guided separation was repeated using various chromatographic techniques, and LC-MS/MS analysis was carried out on the active fraction 
to determine the peptide sequences. Thereafter, the deduced peptides were prepared using a peptide synthesiser and their sequences were confirmed by comparison with the peptides present in SMPs. As shown in Table 3, 12 active di-, triand tetrapeptides, including Phe-Pro-Val-Gly, Leu-Pro-ValLeu, Val-Pro-Phe-Pro and Ile-Pro-Leu as four new DPP-IV inhibitory peptides, were identified. We also observed that all of the these peptides contain Pro at the second position from the N-terminus. As already noted, DPP-IV is a serine protease that recognises and cleaves to the second Pro or Ala residue from the $\mathrm{N}$-terminus of peptides, showing a strong activity against peptides possessing Pro and Ala at this position (Davy et al. 2000). Indeed, it has also been demonstrated that most peptides with DPP-IV inhibitory activity have Pro at the second position. Therefore, among the 12 peptides identified from SMPs, the DPP-IV inhibitory activity of eight peptides has already been reported. Specifically, Ile-Pro-Ile, Val-Pro-Leu and Val-Pro-Ile have been reported as Diprotins A, B and C, respectively (Umezawa et al. 1984; Wiedeman and Trevillyan 2003), whereas Leu-Pro-Leu has been reported as the DPP-IV inhibitory peptide present in milk protein-derived peptides (Nongonierma and FitzGerald 2014). Leu-Pro-Phe was first reported to have angiotensinconverting enzyme inhibitory activity (Wu et al. 2006). Furthermore, a patent application has been filed for LeuPro-Phe, which is present in zein hydrolysates, owing to its DPP-IV inhibitory activity (Hara et al. 2011). The dipeptides Ile-Pro, Leu-Pro and Phe-Pro, which are known to be present in many food materials, have been reported to exhibit DPPIV inhibitory activity (Endröczi et al.1990; Hatanaka et al. 2012). Moreover, to the best of our knowledge, the tetrapeptides Phe-Pro-Val-Gly, Leu-Pro-Val-Leu and Val-Pro-PhePro, as well as the tripeptide Ile-Pro-Leu, all of which were identified in our SMPs sample, are novel. Overall, our results suggest that these components are involved in the DPP-IV inhibitory activity of SMPs.

The $\mathrm{IC}_{50}$ values and contents of these identified peptides were investigated to calculate their respective contribution ratios to DPP-IV inhibitory activity as previously described (Seki et al. 1996). Among the identified peptides, Ile-Pro was found to make the highest contribution to DPP-IV inhibitory activity $(1.3 \%)$, followed by Val-Pro-Phe-Pro (0.9\%). Overall, SMPs were found to be a mixture of several active DPP-IV inhibitory peptides that showed combined DPP-IV inhibitory activity, with Ile-Pro being the most active fraction (i.e. fraction 3-2), implying that it is the core peptide responsible for the DPP-IV inhibitory activity of SMPs. More proline-containing active peptides were obtained from salmon milt in comparison to muscle, probably because the proline content of salmon milt was $6.9 \mathrm{~mol} \%$ versus $4.2 \mathrm{~mol} \%$ in muscle (data not shown). These results suggest that SMPs have a relatively stronger DPP-IV inhibitory activity than peptides from other food ingredients.
Overall, this study revealed that SMPs, which is produced from unused resources discarded in large quantities following fishery processing, at an oral dose of $300 \mathrm{mg} / \mathrm{kg}$ exhibited a strong inhibitory activity against DPP-IV and suppressed the increase in blood glucose levels compared with the control, based on the oral starch tolerance test in $\mathrm{SD}$ rats. We also confirmed that SMPs exert a suppressive effect on postprandial hyperglycaemia and is, consequently, a promising potential functional food material. Clinical trials using SMPs have been conducted, and the results will be reported in the near future.

Open Access This article is licensed under a Creative Commons Attribution 4.0 International License, which permits use, sharing, adaptation, distribution and reproduction in any medium or format, as long as you give appropriate credit to the original author(s) and the source, provide a link to the Creative Commons licence, and indicate if changes were made. The images or other third party material in this article are included in the article's Creative Commons licence, unless indicated otherwise in a credit line to the material. If material is not included in the article's Creative Commons licence and your intended use is not permitted by statutory regulation or exceeds the permitted use, you will need to obtain permission directly from the copyright holder. To view a copy of this licence, visit http://creativecommons.org/licenses/by/4.0/.

\section{References}

Andukuri R, Drincic A, Rendell M (2009) Alogliptin: a new addition to the class of DPP-4 inhibitors. Diabetes Metab Syndr Obes 2:117-126

Cermeño M, Stack J, Tobin PR, O’Keeffe MB, Harnedy PA, Stengel DB, FitzGerald RJ (2019) Peptide identification from a Porphyra dioica protein hydrolysate with antioxidant, angiotensin converting enzyme and dipeptidyl peptidase IV inhibitory activities. Food Funct 10:3421-3429

Cheung IWY, Li-Chan ECY (2017) Enzymatic production of protein hydrolysates from steelhead (Oncorhynchus mykiss) skin gelatin as inhibitors of dipeptidyl-peptidase IV and angiotensin-I converting enzyme. J Funct Foods 28:254-264

Davy A, Thomsen KK, Juliano MA, Alves LC, Svendsen I, Simpson DJ (2000) Purification and characterization of barley dipeptidyl peptidase IV. Plant Physiol 122:425-432

Drucker DJ (2003) Enhanceing incretin action for the treatment of type 2 diabetes. Diabetes Care 26:2929-2940

Endröczi E, Hepp J, Sasváry M, Walentin S, Lévay G (1990) Dipeptidyl peptidase IV (DP IV) and superoxide dismutase activity in thymus-derived lymphocytes: effects of inhibitory peptides and $\mathrm{Zn} 2+$ in vitro. Acta Physiol Hung 75:35-44

Gallwitz B (2007) Sitagliptin: profile of a novel DPP-4 inhibitor for the treatment of type 2 diabetes. Drugs Today 43:13-25

Hansen L, Deacon CF, Orskov C, Holst JJ (1999) Glucagon-like peptide-1-(7-36) amide is transformed to glucagon-like peptide-1-(9-36) amide by dipeptidyl peptidase IV in the capillaries supplying the L cells of the porcine intestine. Endocrinology 140:5356-5363

Hara H, Hira T, Asano K (2011) DPP-IV-inhibiting and GLP, 1 secretion-promoting compositions containing zein hydrolysates, and antidiabetic and antiobesity food and drugs containing the compositions. JP Pat Appl 2011:182742 
Hatanaka T, Inoue Y, Arima J, Kumagai Y, Usuki H, Kawakami K, Mukaihara T (2012) Production of dipeptidyl peptidase IV inhibitory peptides from defatted rice bran. Food Chem 134:797-802

Ji W, Zhang C, Ji H (2017a) Purification, identification and molecular mechanism of two dipeptidyl peptidase IV (DPP-IV) inhibitory peptides from Antarctic krill (Euphausia superba) protein hydrolysate. J Chromatogr B Anal Technol Biomed Life Sci 1064:56-61

Ji W, Zhang C, Ji H (2017b) Two novel bioactive peptides from antarctic krill with dual angiotensin converting enzyme and dipeptidyl peptidase IV inhibitory activities. J Food Sci 82:1742-1749

Jin R, Teng X, Shang J, Wang D, Liu N (2020) Identification of novel DPP-IV inhibitory peptides from Atlantic salmon (Salmo salar) skin. Food Res Int 133:109161

Ketnawa S, Suwal S, Huang J, Liceaga AM (2019) Selective separation and characterisation of dual ACE and DPP-IV inhibitory peptides from rainbow trout (Oncorhynchus mykiss) protein hydrolysates. Int J Food Sci Technol 54:1062-1073

Lacroix IME, Meng G, Cheung IWY, Li-Chan ECY (2016) Do whey protein-derived peptides have dual dipeptidyl-peptidase IV and angiotensin I-converting enzyme inhibitory activities? J Funct Foods 21:87-96

Li-Chan ECY, Hunag SL, Jao CL, Ho KP, Hsu KC (2012) Peptides derived from Atlantic salmon skin gelatin as dipeptidyl-peptidase IV inhibitors. J Agric Food Chem 60:973-978

Neves AC, Harnedy PA, O'Keeffe MB, Alashi MA, Aluko RE, FitzGerald RJ (2017a) Peptide identification in a salmon gelatin hydrolysate with antihypertensive, dipeptidyl peptidase IV inhibitory and antioxidant activities. Food Res Int 100:112-120

Neves AC, Harnedy PA, O'Keeffe MB, FitzGerald RJ (2017b) Bioactive peptides from Atlantic salmon (Salmo salar) with angiotensin converting enzyme and dipeptidyl peptidase IV inhibitory, and antioxidant activities. Food Chem 218:396-405

Nongonierma AB, FitzGerald RJ (2013) Dipeptidyl peptidase IV inhibitory properties of a whey protein hydrolysate: Influence of fractionation, stability to simulated gastrointestinal digestion and food-drug interaction. Int Dairy J 32:33-39

Nongonierma AB, FitzGerald RJ (2014) Susceptibility of milk proteinderived peptides to dipeptidyl peptidase IV (DPP- IV) hydrolysis. Food Chem 145:845-852

Nongonierma AB, Paolella S, Mudgil P, Maqsood S, FitzGerald RJ (2018) Identification of novel dipeptidyl peptidase IV (DPP-IV) inhibitory peptides in camel milk protein hydrolysates. Food Chem 244:340-348

Seki E, Osajima K, Matsufuji H, Matsui T, Osajima Y (1996) Quantitative analysis of digestion resistant ACE inhibitory dipeptides by small intestinal mucosa. Nippon Shokuhin Kagaku Kogaku Kaishi 43:967-969 (in Japanese with English abstract)

Tulipano G, Sibilia V, Caroli AM, Cocchi D (2011) Whey proteins as source of dipeptidyl dipeptidase IV (dipeptidyl peptidase-4) inhibitors. Peptides 32:835-838

Umezawa H, Aoyagi T, Ogawa K, Naganawa H, Hamada M, Takeuchi T (1984) Diprotins A and B, inhibitors of dipeptidyl aminopeptidase IV, produced by bacteria. J Antibiot 37:422-425

Wiedeman PE, Trevillyan JM (2003) Dipeptidyl peptidase IV inhibitors for the treatment of impaired glucose tolerance and type 2 diabetes. Cur Opinion Invest Drugs 4:412-420

Wu J, Aluko RE, Nakai S (2006) Structural requirements of angiotensin I- converting enzyme inhibitory peptides: quantitative structureactivity relationship study of di- and tripeptides. J Agric Food Chem 54:732-738

Publisher's Note Springer Nature remains neutral with regard to jurisdictional claims in published maps and institutional affiliations. 